\title{
Psychiatric and other Diseases of Russian Composers
}

\author{
Darko Breitenfeld ${ }^{1}$, Marko Lucijanić ${ }^{1}$, Vesna Lecher-Švarc ${ }^{1}$, Ivan \\ Šimunec ${ }^{1}$, Ankica Akrap ${ }^{1}$, Ruth Švarc ${ }^{1}$ \\ ${ }^{1}$ Croatian Physicians' Music Society, CMA, Zagreb, Croatia
}

\begin{abstract}
In this article the authors are presenting medical diseases of the Russian composers. On the first place the authors analyzed "The Five" (M. A. Balakirev, A.P. Borodin, C.A. Cui, M.P. Musorgski and N. Rimski-Korsakov). "The Five" created special and different musical expression in the contrast to the rest of the Europe. Their work is a spontaneous continuation of one tradition and also the inspiration for the other composers. The other 29 Russian composers and their patographies are presented chronologically.
\end{abstract}

Key words: Russia; composers; diseases; destinies

Copyright $\odot 2021$ KBCSM, Zagreb

e-mail: apr.kbcsm@gmail.com•www.http://apr.kbcsm.hr

\section{Introduction}

Long Russian history was enriched by many achievements, especially in classical music, which reminds us nowadays about power and magnitude of Russian empire culture [1-7].

The center of Russian musical spirit is consisting of "The Five", the group of powerful composers that lived when Russian nationality was needed to be supported by special and different musical expression in the contrast to the rest of the Europe.

They were established by Milij Aleksejevič Balakirev (1837-1910), an unsuccessful student of mathematics and passionate music lover. His creational spirit was continually followed by melancholic and depressed

\section{Correspondence to:}

Darko Breitenfeld, MD,P hD

Derenčinova 25, 10000 Zagreb, Croatia

Phone: + 385917383023

E-mail: darko.breitenfeld@gmail.com mood, which he was overcoming with the help of his friends. Since the age of 21 he was suffering from headaches and gastrointestinal disorders, interpreted as encephalitis. Despite his character that tended to come into conflicts, he made friendships with many people who felt the strength of his musical talent and love to the country. He had a duty to conduct the Russian musical society, but phases of depression turned him away from the people and soon he became unwanted and involved in many financial problems. Environmental circumstances destroyed his health and he died weak after one episode of pneumonia. His heart, which was pathologically augmented, stopped beating at the age of 73. Despite financial collapse, he succeeded to get a place among musical leaders and his huge merit was assembling the other four young, high-educated and musically talented people: Aleksandar Porfirjevič Borodin, Ce- 
zar Antonovič Cui, Modest Petrovič Musorgski and Nikolaj Rimski-Korsakov.

The titles "The Mighty Handful" and "The Five" were given them in bad manner due to their competitive behavior, but they accepted it freely and were named so in musical history.

Young Aleksandar Porfirjevič Borodin (1833-1887) was directed by his mother to study medicine, leaving him dedicated and lacerated all of his life between two major careers: scientific-medical and musical-composing. This was of vital urgency for illegal son of Caucasian aristocrat, but he became, avoiding life stories of similar people, may be the best composer amongst physicians and scientifically and professionally important in the development of medicine. Although he was constantly active, he didn't have time to feed both of his passions. On his death day, he was composing the final part of his $3^{\text {rd }}$ symphony. That evening he also participated in the entertainment for Academy professors where he suddenly fell and lost his conscience. Most probably he died of a heart attack. Very soon his wife died and her sickness was partially responsible for his mental and physical exhaustion.

Cezar Antonovič Cui (1835-1918) as well developed two successful carriers, musical one and army one with social appreciation on both fields. In the end of his life, he became blind and died as a result of cerebral bleeding.

In the winter in 1918 occurred general shortage and hunger and soon the October revolution started due to social disappointment.

Modest Petrovič Musorgski (1839-1881) was a friend of Cui and he as well worked in a public office but in a contrast to Cui, Musorgski was eccentric, addicted to alcohol and he never liked his job. Although that he was born in noble and rich family, he lived disorderly with many episodes of drinking that made him feel anxiety. His partners were men and women, often with unusual predispositions and life habits. A lot of escapes from reality were deeply reflected to his health condition. Despite his social popularity and optimistic effort (due to alcohol), he was alone during crises and he developed severe addiction. He began to have delirium and episodes of alcohol-related epilepsy attacks. Just before his last birthday, he was taken to the hospital in unconscious condition. Thanks to the nurse, he bought an alcohol with a money he got as a birthday gift. He died the same night because of 2 bottles of vodka. Even less would be enough in situation relating to delirium, erysipel, spinal cord inflammation, kidney inflammation and heart and liver failure. Accidentally or not, Wernicke-Korsakov's syndrom (brain damage with typical psychological symptoms caused by alcohol) was described for the first time in 1881, when Musorgski died exactly from this condition.

Nikolaj Rimski-Korsakov (1844-1908), with the same surname like neuro-psychiatrist Korsakov whose surname was given to the above mentioned syndrome, was the last member of "The Five". He was born in an aristocratic family, just like Musorgski, but he had normal life habits as a difference. He developed very successful army carrier. Under protection of the other four members, he was motivated a lot to create and explore music and as musically educated by himself as a compensation of everything he missed during the military education. At the age of 45 , heart artery disease has begun. A general weakness has started with attacks of angina and heartrelated asthma too. He even didn't have the strength to go to the daughter's wedding and soon he died.

Although primary mentioned, these five composers were just one part in this period of time, creating music and influencing each other. Their work is a spontaneous continuation of one tradition and also the inspiration for Glinka and the others.Let's chronologically mention the names of the other significant 
Russian composers with an overview to their diseases.

Aleksej Nikolajevič Verstovski (17991862), son of the Russian general and the Turkish prisoner, had a big influence to the Russian music. Well known as a rival of another great composer, Glinka. As he lost a battle from him and thanks to his professional failure, he became ill to the level characterized as a psychosis and soon he died.

Mihail Ivanovič Glinka (1804-1857) has strongly influenced to his coevals. His character was sensitive and he lost health due to alcohol. Probably, syphilis is the reason for his paranoid syndrome in the last year of his life. He developed fatal pneumonia as a result of a mild flu he didn't recognized. Severe liver cirrhosis was discovered at the autopsy.

Aleksandar Sergejevič Dargomižski (1813-1869) was born in a rich landholding family. He enjoyed music as an amateur and the acquaintance with powerful five composers has influenced strongly his creation. He was chronically ill (he suffered of rheumatoid symptoms) and died relatively young, probably from rheumatic damaged heart.

Pavel Andrejevič Fedotov (1815-1852) was very talented artist, composer and painter. Since adolescence, he was mentally ill and at the age of 37 he died at the psychiatric institution as a result of psychosis.

Anton Grigorevič Rubinstein (18291894) was a talented pianist and composer. He was influenced by many foreign music ideals due to numerous journeys and often objected for ignoring Russian traditional music. He established Russian music society. At the age of 64 he got a stroke which was the direct cause of his death.

Nikolaj Grigorevič Rubinstein (18351881) was a younger brother of Anton Grigorevič Rubinstein, and was less active as a composer, but fully engaged on development and promotion of music. He really enjoyed eating a lot of different food and soon he developed digestive problems which were lately approved as an intestinal form of tuberculosis. Once, while he was eating oysters, he was taken to the hospital with an acute abdomen which was the cause of his death.

Petar Iljič Čajkovski (1840-1893) lost his mother as a child. He was educated in the army where he got his first homosexual experiences. At this time, this secret, hidden from the public, was a hard burden for him. Therefore, his depressive episodes, which were following him since he was an adolescent, were activated with an alcohol addiction as a result. He combined alcohol and bromine together trying to achieve relaxation and deprivation of his sexual instincts. During his life he had attempted suicide several times and finally he committed suicide by drinking a glass of water from river Neva. This is an official version of that event. After he had drunk water, he died of dysentery followed by abdominal spasms and severe diarrhea. The other version suggests that he poisoned himself on purpose with arsenic, the poison which causes the same clinical symptoms. The reason for that deed was probably a seduction of a young 14-years old boy from a powerful family Therefore the Russian emperor even founded specific committee for the investigation.

Anton Stepanovič Arenski (1861-1906) His life was so wasteful; his hair was disheveled and he fulfilled himself with gambling and alcohol. He early got tuberculosis and died at the age of 45 .

Aleksander Konstantinovič Glazunov (1865-1936) went on a tour to Europe and America. He left Russia due to the political circumstances and lived as an emigrant in France. His health was disturbed by alcohol and he died very soon.

Vasilj Sergejevič Kalinikov (1866-1901) was born in a musical family which invested a lot in his musical education. He was composing until he died very early. Since adoles- 
cence his health was fragile, and was additional reduced during studying due to poverty and poor nutrition when tuberculosis developed and caused his death.

Aleksander Nikolajevič Skrjabin (18721915) was popular composer and was favored by his students. He was often in relationships with both genders. At the age of 42, furunculus became to develop on his upper lip and it progressed to a carbuncle that was surgically removed. After transitory enhancement, high temperatures, sepsis and meningitis were the cause of his death.

Sergej Vasiljevič Rahmanjinov (18731943) had huge hands, with long and mobile fingers which enabled very sophisticated interpretation of his music and music from the other composers. At the beginning of the October Revolution, he left his country travelling worldwide with America as his final destination. He suffered from rheumatic symptoms, frequent prickles on the top of the fingers and arthritic symptoms which he treated several times. This was result of his physiognomy, Marfan's syndrome maybe (congenital weakness of connective tissue with long and too flexible fingers as a result). During the radiologic search, the shadow in the lungs was seen. It was a metastasis of a malignant melanoma.

Igor Fjodorovič Stravinski (1882-1971) has a reputation to be the most important composer in the 20th century. His life was difficult and characterized by many family tragedies (predisposition for tuberculosis in the whole family). Since adolescence, he had tuberculosis but cured it successfully. After the World War I and the Revolution, he was living mostly abroad and composing a lot. In 1938, his daughter and his wife died from tuberculosis. These two big tragedies within existence problems supported relapse of his tuberculosis at the beginning of the World War II. He was a stubborn smoker with generalized atherosclerosis as a result. While he was in America, he aged 89 years and thanks to the best medical care and treatment of several exacerbations of tuberculosis, peripheral artery disease and two strokes.

Aleksej Vladimirevič Stančinski (18881914) got psychosis as a young man and at the age of 26 he committed suicide by drowning.

Sergej Sergejevič Prokofjev (1891-1953) was a passionate smoker. This addiction led to hypertension followed by headaches, vertigo and bleeding from the nose. As a result of hypertension and a lot of head impacts, he got several strokes but last stroke was fatal at the age of 61.

Varion Jakovljevič Šebalin (1902-1963) got a stroke at the age of 51 but he succeeded to write and compose with his left hand for 10 years after that. In the end, he died from one more stroke.

Dmitrij Borisovič Kabalevski (19041987) died at the age of 83 from general senile failure.

Dmitrij Dmitrijevič Šostakovič (19061975) got tuberculosis very early but he recovered successfully. Despite severe lung symptoms, he didn't stop smoking so the symptoms were present all the time. Neurologic symptoms started soon, followed by loss of sensation and weakness in the fingers that were soon spreading to the legs. It is unknown what disease it really was. It was perhaps amyotrophic lateral sclerosis associated with spastic walk and difficulty in playing piano (inability in rising hands). After that, he got two heart attacks as a result of smoking. Finally, he got liver cancer and soon he died at the age of 68 as a result of one more heart attack.

We will mention other important composers and the reasons of their death:

Dmitrij Bortnjanski (1751-1825) - senile failure

Aleksandar Guriljov (1803-1858) - progressive paralysis due to syphilis 
Aleksandar Sjerov (1820-1871) - heart attack

Anatolij Ljadov (1855-1914) - bronchitis, pneumonia, cardiomyopathy

Sergej Tanjejev (1856-1915) - pneumonia

Mihail Ipolitov - Ivanov (1859-1935) senile failure

Aleksandar Grečaninov (1864-1956) senile failure

Reinhold Gliere (1875-1956) - heart attack

Nikolaj Mjaskovski (1881-1950) - cancer

Jurij Šaporin (1887-1966) - senile failure

Alfred Schnittke (1934-1998) - strokes

In this article the authors presented Russian composers. They were living in a time when medical procedures were not as developed as they are now, as well as successful medical

\section{References}

1. Breitenfeld D, Breitenfeld T. Bolesti i sudbine poznatih skladatelja. Zagreb: Music Play; 2012.

2. Sadie S. Grove. World Encyclopedia of Music, London; McMillan: 1980.

3. Neumayr A. Musik und Medizin. Wien: J\&V Edition Wien;1989.

4. Greene D.M. Greene's Biographical Encyclopedia of Composers. Garden City, New York: Doubleday \& Company Inc; 1985. therapy was still undeveloped. We established that the main reasons for deaths of the Russian composers were senile failure (5), stroke (5), heart attack (4), chronic heart disease (3), tuberculosis (3), pneumonia (3), psychosis (2), malignant diseases (2), suicide (2), alcohol (2), cerebral bleeding (1), sepsis (1) and syphilis (1). They died because of acute or chronic disease, which is understandable regarding the age of the composers. Longevity in this sample averaged 61,76 years, similar to that of other world composers.

\section{Acknowledgements}

None.

\section{Conflict of Interest}

None to declare.

5. Breitenfeld T. Neurološke i psihijatrijske bolesti skladatelja (magistarski rad). Zagreb: Stomatološki fakultet Sveučilišta u Zagrebu; 2006.

6. O'Shea J. Music and Medicine Medical Profiles of Great Composers. London: J.M. Dent \& Sons Ltd.; 1990.

7. Lewis JW Jr. What Killed the great and Not so Great Composers? Bloomington: Author House; 2010.

\section{Psihijatrijska i druga oboljenja ruskih skladatelja}

Sažetak- U radu autori iznose medicinske bolesti ruskih skladatelja. Prvenstveno autori analiziraju "Petoricu" (M. A. Balakirev, A.P. Borodin, C.A. Cui, M.P. Musorgski and N. Rimski-Korsakov). "Petorica" su kreirala posebni i drugačiji muzički izričaj nasuprost onome u drugom dijelu Europe. Njihov izričaj je spontani nastavak jedne tradicije, ali je i inspiracija za druge skladatelje. Kronološkim su redom iznesene i patografije drugih 29 ruskih skladatelja.

Ključne riječi: Rusija; skladatelji; bolesti; sudbine 
